\title{
Literatürde Organik Tarım Terminolojisi: Organik Tarımla İlişkili Dergilerde Bir İçerik Analizi
}

\author{
Ramazan Okuduma, Faruk Alaeddinoğlu ${ }^{b^{*}}$, Mehmet Şeremet ${ }^{c}$ \\ a,bYüzüncü Yıl üniversitesi, Edebiyat Fakültesi, Coğrafya Bölümü, Van. \\ cYüzüncü Yıl Üniversitesi, Denizcilik Fakültesi, Van.
}

\section{Öz}

İnsanoğlunun ekolojik ve sosyal çevresi üzerinde olumlu bir etkiye sahip ve ayn zamanda gelecek vaat eden (Vogl vd, 2005: 5) organik tarım, tüm dünyada gün geçtikçe önemi artan bir tarımsal yöntem haline dönüşmektedir. Bu bağlamda yükselen bir değer olan organik tarım, bu araştırmanın konusu olmuştur. Araştırmaciların organik tarımla ilgili değişkenler konusunda daha fazla bilgi sahibi olmaların amaçlayan bu çalışma, derleme türünde bir araştırma niteliğindedir. Çalışma kapsamında, organik tarım ve ilgili değişkenleri içeren 30 dergi tespit edilmiştir. Bu dergiler arasından konulara ilgililik düzeylerine ve dergilerin ISI etki faktörlerine göre tekrar bir filtreleme uygulanarak dergi sayısı 11'e indirilmiştir. Bu filtreleme işleminde temel belirleyici olan unsur dergilerin sahip olduklarn 'etki faktörleridir' (ISI knowledge tarafindan sağlanan 'impact factor'). İkinci bir filtreleme kriteri ise dergilerin basim yeri ve editörlerin görev yaptıkları ülkelerdir. Organik tarım konusunda Avrupa ve Kuzey Amerika ülkeleri daha köklü bir geçmişe ve tecrübeye sahip olmalarından dolayı dergilerin basım yerlerinin ve editörlerin görev yaptıkları yerlerin adı geçen ülkelerden olmasına özen gösterilmiştir. Sonraki aşamada ise belirtilen dergilerde tarama işlemine başlanmış ve bu süreç 11.06.2015 tarihinden 24.12.2015 tarihine kadar devam etmiştir. Sonuç olarak; 118 makalenin literatür analizine göre aşağıda ifade edilen maddeler çerçevesinde organik tarımın kırsal kalkınma ilişkisinin ele alınabileceği noktalar ortaya konulmuştur: (1) organik tarımın ekonomik çarpan etkisi ve kırsal istihdam yaratma potansiyeli vardır; (2) organik üretim sertifikasına sahip olan üreticiler bulunmaktadı; (3) organik üretim sertifikasına sahip olmayan diğer üreticilerle kıyaslandığında daha fazla gelir elde etmektedir; 84) Organik tarım konvansiyonel tarıma göre daha sürdürülebilir bir tarımsal üretim şeklidir; (5) Organik tarım, çevre dostu bir uygulamadır; (6) Hükümet Dışı Organizasyonlar (HDO) organik ürünün yetiştirilmesinden pazarlanmasına kadar pek çok konuda organik üretime olumlu katkı sunmaktadır.

Anahtar Kelimeler: Organik Tarım, Literatür Tarama, Sürdürülebilir Kırsal Kalkınma, Çevre Koruma.

\section{Organic Farming Terminology in the Literature: A Content Analysis of Journals in Organic Farming}

\begin{abstract}
Organic farming which is defined as "a promising farming method having positive effect on ecological and social environment of human" (Vogl et al. 2005, 5), has been globally important agricultural method. Organic farming, which is a rising value, has been the subject of this research. This study, which aims to contribute researchers is a literature review on organic farming. On the basis of review methodology, 30 journals related to organic farming were determined. Of these 30 journals, re-selection was performed according to the relevancy to the subject (namely organic farming) and the journals' ISI impact factors. The number of journals are reduced to 11. In this filtering process, the basic determinant was 'impact factors' of the journals
\end{abstract}


(impact factor provided by ISI knowledge). A second filtering criteria was made with respect to publishing house and countries where the journals are published. Because the countries in Europe and in the USA having greater experience in organic farming, journals are selected from these countries. Analyzing process in the selected journals is proceeded from 11.06.2015 until 24.12.2015. As a consequence; according to the results of 118 papers analyzed, the articles were listed to underline the following subjects in ranging from organic farming to rural development: (1) organic farming robust the economy and increases the employment opportunities in rural areas; (2) there are farmers having organic-production certification; (3) farmers having organicproduction certification earn more money than farmers not having organic-production certification; (4) organic farming is a more sustainable production method when compared to conventional farming; (5) organic farming is an eco-friendly application; (6) Non-Governmental Organizations (NGOs) have contributions on raising and marketing organic goods.

Keywords: Organic Farming, Literature Review, Sustainable Rural Development, Ecological Conservation.

\section{Gİiș}

Modern ve post-modern süreçler öncelikli olarak kırsal kalkınmayı sonrasında ise organik tarımı (veya organik yetiştiriciliği) gelişmiş ve yakın zamanda ise gelişmekte olan ülkelerin gündemine taşımıştır. Özellikle son 50 yıllık dönem 'sürdürülebilirlik' kavramının dünya çapında ele alınması bu üretim tarzını daha popüler kılmıştır. Zira artan dünya nüfusu kırsal kaynakların daha iyi yönetilmesini gerektirmiştir. Gelişmiş ülkelerde kentleri besleyen kırsal alanların boşalmaya başlaması ve kırsal kaynakların sürdürülebilirliğinin tehlikeye girmesi sürdürülebilir kırsal kalkınmanın önemini artırmıştır.

Kırsal kalkınmayı tesis etmede kullanılan önemli kriterlerden birisi mekânın sürdürülebilirliği, bir diğeri ise mekânın karar vericisi olan insanın sahip olduğu sosyo-kültürel sermayenin devamlılığıdır (Alaeddinoğlu ve Şeremet, 2016). Yani bir mekân, onu oluşturan bireylerden bağımsız olarak düşünülemeyeceği gibi bir birey de onun sosyal ve kültürel özelliklerinden bağımsız düşünülemez. Zira bireylerin veya kırsal topluluğun sahip olduğu sosyo-kültürel özellikler onun uyguladığı ekonomik faaliyetlerden ve bunu neden uyguladığından, yaşam tarzından, olaylar ve sorunlar karşısındaki yaklaşımından, sosyal ilişkilerinden bağımsız değildir. Bu yüzden, kırsal kalkınmanın sağlıklı bir şekilde başarılabilmesi için mekânsal özellikler kadar kırsal topluluğu oluşturan bireylerin ve onların sosyo-kültürel özelliklerinin de iyi bir şekilde analiz edilmesi gerekmektedir.

Kaynakların sürdürülebilirliğin tehlikeye girdiğini en yüksek düzeyde dile getiren kuruluş Birleşmiş Milletler (BM)'dir. Bu süreç öncelikle 1972'de Roma Kulübü'nün 'Büyümenin Sınırları' başlıklı raporunda ve yine aynı yıl Stockholm'de (İsveç) düzenlenen 'Birleşmiş Milletler İnsan Çevresi Konferansı'nda dile getirilmiştir. Şüphesiz bunlar içerisinde 1992 Rio Konferansı, çoğu ülkenin katılımından dolayı küresel bir önem kazanmıştır. Konferansta Rio Deklarasyonu ve Gündem 21 adlı iki temel belge kabul edilmiştir. Sonrasında ise Johannesburg'ta (Güney Afrika) 'BM Dünya Sürdürülebilir Kalkınma Zirvesi' yapılmıştır. Bu konferanslar, çevresel sürdürülebilirliğe dikkat çeken başlıca konferanslar olmuştur (www.un.org). 
1940'lı yıllarda dile getirilmeye başlanan kırsal kalkınma kavramı, kentlere göre sosyal, kültürel ve ekonomik anlamda dezavantajlı olan kentlerin gelişmesine katkı sunmayı amaçlamaktadır. Ancak küresel anlamda sürdürülebilirliğin ciddi bir mesele haline gelmeye başlaması, kırsal kalkınmayı da bu konuda önlemler almaya yöneltmiştir. Bu bağlamda kırsal kalkınma kavramı boyut değiştirerek sürdürülebilir kırsal kalkınma şeklinde daha çok ifade edilir olmuştur. Sürdürülebilir kırsal kalkınma ile organik tarım ele alındığında aslında sürdürülebilir kırsal kalkınmanın özüne en uygun kırsal planlama uygulamasının organik tarım olması gerektiği düşünülmektedir. Çünkü konvansiyonel tarım, turizm, ticaret ve imalat gibi kırsal kalkınmanın aracı olan tüm uygulamalarla kıyaslandığında organik tarım hem daha sürdürülebilir hem de daha kârlı bir araçtır. $\mathrm{Bu}$ yönüyle düşünüldüğünde 'sürdürülebilir kırsal kalkınma' uygulamalarıyla 'organik tarım' uygulamaları birbiriyle son derece yakın ilişkilidir (Smith ve Marsden, 2004). Sonraki bölümlerde ortaya konulacağı gibi literatür bulguları da organik tarımın sürdürülebilir kırsal kalkınmaya olan katkısı üzerinde yoğun olarak durmaktadır.

Organik tarımın dünyadaki gelişim süreci yakın tarih açısından kısaca ele alınacak olursa Avrupa ve Amerika Birleşik Devletleri'nde başlamış sonrasında diğer ülkelere yayılmıştır (Yavuzer ve Bengisu, 2015). 1972 yılında Uluslararası Organik Tarım Hareketleri Federasyonu'nun (IFOAM-International Federation of Organic Agriculture Movements) kurulmasıyla yeni bir sürece girilmiştir. Merkezi Almanya'da olan bu kuruluş tüm dünyada organik üretime ilişkin kuralları yönetmelikler aracılığıyla ilk olarak tanımlayan kuruluştur. Avrupa Birliği'ndeki ilk yasal düzenlemeler ise 1991 y1lında yürürlüğe girmiştir (Balaban, 2014).

Organik Tarım Araştırma Enstitüsü (FIBL-Forschunginstitut für biologischen Landbau) ve IFOAM'ın 2010 yılı sonunda yayınladığı verilere göre dünyada organik tarım yapılan alan miktarının neredeyse organik olmayan tarım alanları miktarına yaklaştığını göstermektedir. Dünyada 43 milyon hektarlık organik olmayan tarım alanına karşılık 37 milyon hektar organik tarım alanı bulunmaktadır. Bu toprakları ise 1.6 milyon üretici tarafından işlenmektedir. Bunların da \%80'i gelişmekte olan ülkelerdedir. En fazla organik ürün yetiştirilen alana sahip ülkeler sırasıyla Avustralya, Arjantin, ABD, Brezilya, İspanya ve Çin'dir. Türkiye ise 2010 yılında bir önceki yıla göre organik tarım alanlarını en fazla arttıran 5 ülke arasına girmiştir (Balaban, 2014; Yavuzer ve Bengisu, 2015; FIBL, 2012 ve IFOAM, 2012).

Çevre ve sağlıkla ilgili kaygılar organik tarıma olan ilgiyi arttırmıştır. Talep ve çiftçi sayısındaki artış organik tarım ticaretini de canlandırmıştır. Kendi ülkelerinde organik ürünler için iç pazar ve talep olmadığı halde bazı ülkeler, Avrupa'da yetişmeyen ve talep edilen organik ürünleri farklı ülkelerde üretme ve ihraç etme yoluna gitmişlerdir (Yavuzer ve Bengisu, 2015). Türkiye'de de organik tarımın gelişim süreci bu şekilde ortaya çıkmıştır. 1984 yılında Avrupa'nın talebiyle İzmir'de kuru üzüm ve kuru incir yetiştiriciliği Türkiye' de organik tarım sürecini başlatmıştır. Daha sonra ise organik kayısı üretimi başlamıştır. İlk yıllarda Avrupa kökenli bazı şirketlerin kendi ihtiyaçları doğrultusunda üretim gerçekleştirilirken 1990'lı yılların başında Türk uzmanların yetişmesiyle organik ürün yetiştiriciliği yerelleşmeye başlamıştır (Balaban, 
2014). Kırsal ekonomilerin turizm yoluyla çeşitlendirilmesini destekleyen yasal ve politik çevrenin geliştirilmesine yönelik çalışmalar (Ayaz, 2015) kapsamında da organik tarım uygulamaları önem arz eder hale gelmiştir.

\section{Araştırma Yöntemi}

Organik tarım üzerine bir literatür analizini içeren bu çalışma 4 aşamadan oluşmaktadır (Tablo 1). I. Aşamada organik tarım konusunu ağırlıklı olarak ele alan dergilerin araştırılmasıyla işleme başlanmıştır. Bu süreçte 30 dergi tespit edilmiştir. II. Aşamada ise bu dergiler arasından konuların ilgililik düzeylerine ve dergilerin ISI impact faktörlerine göre tekrar bir filtrelemeye gidilerek dergi sayısı 11'e indirilmiştir. $\mathrm{Bu}$ filtreleme işleminde ise asıl belirleyici olan unsur dergilerin sahip oldukları 'etki faktörleridir' (ISI knowledge tarafından sağlanan impact factor). İkinci bir filtreleme kriteri ise ülkelerin organik tarım konusundaki tecrübeleridir. Organik tarım konusunda Avrupa ve Kuzey Amerika ülkeleri daha köklü bir geçmişe ve tecrübeye sahip olmalarından dolayı dergilerin basım evlerinin ve editörlerin görev yaptıkları ülkelerin Avrupa ve Kuzey Amerika ülkelerinden olmasına özen gösterilmiştir. Sonraki aşamada (III) ise belirtilen dergilerde makale tarama işlemine başlanmış ve tarama işlemi 11.06.2015 tarihinden başlayıp 24.12.2015 tarihinde sona ermiştir (yaklaşık olarak 6 aylık bir süreç). Literatür tarama işlemi İngilizce dilinde yapılmıştır. Tarama işlemi şu terimler ve kombinasyonlarını içerecek şekilde sıralanan mantıksal dizgiye göre yapılmıştır: ('organic' VE/VEYA 'ecological' VE/VEYA 'biological' VE/VEYA 'farming') VEYA ('organic' VE/VEYA 'ecological' VE/VEYA 'biological' VE/VEYA 'agriculture'). Makalelerin başlığına göre yapılan bu filtreleme işleminin sonucunda 11 dergi için ayrı ayrı klasör dosya oluşturulmuş ve makaleler yayınlandıkları dergi ismine göre klasörlere kaydedilmiştir (Tablo 2). Bu işlemin sonucunda 387 adet çalışmaya ulaşılmıştır. IV. Aşamada ise bu makaleler üzerinde tekrar bir filtrelemeye gidilmiştir. Bunun sebebi ise Coğrafya disipliniyle daha yakından ilişkili konuları ele alan makaleler üzerine yoğunlaşma çabasıdır. Kapsama alınmayan makaleleri ise ağırlıklı olarak biyoloji, ziraat, tıp, veterinerlik gibi alanlardaki araştırmacılar tarafından yazılan laboratuvar analizlerine dayanan teknik çalışmalarıdır. Bu süreçte ilk olarak çalışmanın özeti okunmuş daha sonrasında ise ana çerçeve üzerinde bir değerlendirme yapılmıştır. Bu işlemin sonucunda ise 118 çalışmanın üzerinde yoğunlaşmaya karar verilmiş ve literatür okuması gerçekleştirilmiştir. 
Tablo 1. Literatür Analizi Çalışmasının Aşamaları

\begin{tabular}{|c|c|c|c|}
\hline Aşama & Hedef & Kriter & Çıktı \\
\hline I & Dergi araştırma & Organik tarım kavramı & $\begin{array}{c}\text { Konuyla ilgili 30 } \\
\text { derginin tespiti }\end{array}$ \\
\hline II & $\begin{array}{c}30 \text { dergide } \\
\text { filtreleme }\end{array}$ & $\begin{array}{c}\text { Dergilerin etki faktörü ve } \\
\text { ülkelerin organik tarım } \\
\text { tecrübesi }\end{array}$ & $\begin{array}{c}\text { Dergi sayısının 11'e } \\
\text { indirilmesi }\end{array}$ \\
\hline III & $\begin{array}{c}\text { Dergilerde makale } \\
\text { tarama }\end{array}$ & $\begin{array}{c}\text { Anahtar kelimeler } \\
\text { (Örneğin organic farming) }\end{array}$ & 387 makalenin tespiti \\
\hline IV & $\begin{array}{c}\text { İçeriğe göre yeniden } \\
\text { filtreleme }\end{array}$ & $\begin{array}{c}\text { Özetin ve genel çerçevenin } \\
\text { değerlendirilmesi }\end{array}$ & $\begin{array}{c}118 \text { makalenin kapsama } \\
\text { alınması }\end{array}$ \\
\hline
\end{tabular}

Tablo 2. Analiz Kapsamına Alınan Dergilere Ait Bilgiler

\begin{tabular}{|c|c|c|c|c|}
\hline Sayı & Dergi Adı & $\begin{array}{l}\text { Derginin Basıldığı } \\
\text { Ülke }\end{array}$ & $\begin{array}{c}\text { Editörlerin Görev } \\
\text { Yaptığı Ülke }\end{array}$ & $\begin{array}{c}\text { Etki Faktörü } \\
\text { (Impact Factor) }\end{array}$ \\
\hline 1 & $\begin{array}{l}\text { The Journal of } \\
\text { Peasant Studies }\end{array}$ & Hollanda & Hollanda & 4,553 \\
\hline 2 & $\begin{array}{c}\text { Agriculture, } \\
\text { Ecosystems and } \\
\text { Environment }\end{array}$ & Hollanda & İsviçre & 3.402 \\
\hline 3 & $\begin{array}{c}\text { Journal of } \\
\text { Environmental } \\
\text { Planning and } \\
\text { Management }\end{array}$ & İngiltere & $\mathrm{ABD}$ & 2,723 \\
\hline 4 & Land Use Policy & İngiltere & Avustralya & 2,631 \\
\hline 5 & $\begin{array}{c}\text { Journal of Rural } \\
\text { Studies } \\
\end{array}$ & İngiltere & İngiltere & 2.444 \\
\hline 6 & World Development & Hollanda & $\mathrm{ABD}$ & 1,965 \\
\hline 7 & Food Policy & Hollanda & İtalya-ABD & 1,799 \\
\hline 8 & $\begin{array}{c}\text { Environmental } \\
\text { Management }\end{array}$ & $\mathrm{ABD}$ & $\mathrm{ABD}$ & 1,724 \\
\hline 9 & $\begin{array}{c}\text { Agriculture and } \\
\text { Human Values }\end{array}$ & $\mathrm{ABD}$ & $\mathrm{ABD}$ & 1.617 \\
\hline 10 & $\begin{array}{l}\text { Development and } \\
\text { Change }\end{array}$ & İngiltere & Hollanda & 1,561 \\
\hline 11 & Sociologia Ruralis & İngiltere & Hollanda & 1,306 \\
\hline
\end{tabular}

\section{Bulgular}

Literatür tarama sürecinde elde edilen bulgular 6 başlık altında toplanmıştır. Bunlar (1) organik tarımın kırsal kalkınmaya katkısı, (2) organik tarım politikaları, (3) sertifikasyon sistemi, (4) hükümet dışı organizasyonların rolü, (5) konvansiyonel tarım ve (6) tüketici motivasyonudur. Sayıları çok az olmakla birlikte her bir kavramı farklı 
açılardan ele alan pek çok çalışma mevcuttur. Ancak literatür bulgularındaki genel odak noktaları bu 6 başlık altında ele alınmıştır.

\subsection{Organik Tarım ve Sürdürülebilir Kırsal Kalkınma İlişkisi}

Organik tarım ve sürdürülebilir kırsal kalkınma birbiriyle son derece yakın bir ilişki içerisindedir (Smith ve Marsden, 2004; Lockie ve Halpin, 2005 ve Pugliese, 2001). $\mathrm{Bu}$ kapsamda hem organik tarımın hem de kırsal kalkınmanın temel prensiplerinin birbiriyle büyük oranda örtüştüğü görülmektedir. Moseley'in kırsal kalkınma tanımında, üzerinde özellikle durduğu 12 kavramın, organik tarımın temel prensipleriyle de benzerlikler gösterdiği anlaşılmaktadır. Ona göre kırsal kalkınma şu şekilde tanımlanmalıdır:

“Tüm topluluğun uzun dönemli refahını geliştirmek için tasarlanan çevresel, ekonomik, sosyal ve kültürel değişimin sürdürülebilir ve sürdürülen sürecidir" (Moseley, 2003: 4).

Organik tarım ve kırsal kalkınma arasındaki ilişki ağırlıklı olarak ekonomik perspektiften ele alınmıştır. Zira, organik tarımın çoğaltan etkisi, kırsal istihdama katkısı ve organik ürün ticaretinin daha karlı bir uğraş olması onun kırsal ekonomi üzerindeki etkisini ortaya koymaktadır. Organik tarımın geniş çevrelerce bilinen bu etkisi literatür bulgularıyla da ortaya konmuştur. Brezilya ve İngiltere örneklerinde organik tarım, küçük üreticilerin geçimliğini arttırmak ve geliri yükseltmek için potansiyel bir çözüm olarak görülürken (Blanc ve Kledal, 2012 ve Smith ve Marsden, 2004) Polonya'da devlet desteğinden yararlanan yetiştiricilerin tarımsal motivasyonunu yükselterek onların çevreye ve kırsal kalkınmaya katkı sunmaları sağlanmıştır (De Master, 2012). Kenya örneğinde ise organik tarımın yoksulluğu azaltmada olumlu etkiye sahip olduğu ortaya konmuştur (Ayuya vd, 2015). Bu konudaki yaygın görüşlerden bir diğeri organik tarımın istihdamı arttırdığı yönündedir. İngiltere (Lobley vd, 2009) ve Japonya'da (McGreevy, 2012) yapilan çalışmalarda ise organik tarımın istihdamı arttırarak kırsal kalkınmaya olumlu etkide bulunduğu ortaya konmuştur.

\subsection{Organik Tarım Politika ve Programları}

Tarımsal ve çevresel sürdürülebilirlik politikalarının önem kazandığı son zamanlarda en büyük eleştirilerden birisi mevcut tarımsal politikalara gelmiştir. Zira konvansiyonel tarım olarak da bilinen modern tarım uygulamalarının doğa ve insan üzerindeki olumsuz etkilerinin zamanla ortaya çıkması konvansiyonel tarıma çeşitli eleştirilerin yöneltilmesine ve sivil tepkilerin ortaya çıkmasına neden olmuştur. Bu süreç, daha çevre dostu ve sağlıklı bir tarımsal yöntem arayışıyla sonuçlanmıştır (Vos, 2000). Bu konuda, geniş çevrelerin talebini karşılayan uygulama 'sertifikalı organik tarım' çalışmaları olmuştur. Ürünlerin belirli standartlar çerçevesinde insan ve çevre dostu olarak yetiştirildiği bu yöntemin uluslararası boyut kazanması ilk olarak 1972 yılında Uluslararası Organik Tarım Hareketleri Federasyonu'nun (IFOAM) kurulmasıyla başlamıştır. Öncülüğünü $A B$ ve $A B D^{\prime}$ nin yaptığı organik tarım 
hareketleri küresel boyutta giderek önem kazanan yeni bir tarım sistemini ve 'daha çevreci bir yaşam tarzını' meydana getirmiştir.

Daha sonraki aşamada organik tarım politikaları ve buna bağlı olarak da uygulamaları sürekli bir gelişim, değişim ve dönüşüm süreci içerisine girmiştir. Organik tarıma yönelik atılan bu adımlar ulusal tarım politikaları ve $A B$ ortak tarım politikaları aracılığıyla uygulamaya konmuştur. Bu konuda öncülüğü AB'nin yaptığı söylenebilir. 1990'lı yılların başında organik tarımın tanımlanması ve sektördeki tarımçevre dostu uygulamalara finansal destek imkânlarıyla organik tarımın 'Avrupalılaştığı' ifade edilmiştir (Michelsen, 2009). Organik tarımın gelecekte Avrupa'nın tarım politikasını şekillendireceği ve kırsal kalkınmada önemli bir aktör olacağ1 siyasi karar alıcılar tarafından ileri sürülmüştür (Smith ve Marsden, 2004). Bu bakış açısı çerçevesinde organik tarım sektörünün önündeki bazı problemlerin farklı politik müdahalelerle çözüme kavuşturulması veya politik müdahalelerle sektörün desteklenmesi gelişim sürecini ve katılımı hızlandırmıştır (Stolze ve Lampkin, 2009; Haring vd, 2009; Daugbjerg vd, 2011 ve Offermann vd, 2009). ABD'de ise organik tarıma yönelik artan sivil destekler (Vos, 2000) ve organik tarımı geliştirmeye yönelik fonlar ve politikalar daha sürdürülebilir bir tarım uygulamasının hayata geçmesine neden olmuştur (Marshall, 2000).

\subsection{Organik Tarımda Sertifikasyon Sistemi}

Organik üründe sertifikasyon sistemi önemli bir yere sahiptir. Zira bu sistemle organik ürünlerin belirli bir standartta yetiştirilmesi, denetlenmesi ve markalandırılması sağlanmaktadır. Sertifikasyon sistemi gıdaların güvenliği, sağlığı, kalitesi ve standardizasyonu konularında konvansiyonel ürünlerle kıyaslandığında üreticilere daha fazla güven vermektedir. Tüketiciler açısından sertifikalı ürünün çevre dostu olduğu (Sonderskov ve Daugbjerg, 2011), katı standartlarda kontrol mantığıyla üretildiği ve girişimcilerin sürece sadık kaldığı gibi konular yaygın bir şekilde kabul görürken (Zagata ve Lostak, 2012), üreticiler ise sertifikasyon sisteminin sağlamış olduğu avantajları kullanarak daha az miktarda ürün elde etmelerine rağmen birim miktardaki satışta bir kaç kat daha fazla gelir elde etmektedir.

Kuzey Nikaragua'da yapılan saha çalışmasında organik tarıma katılımın, üreticilerin kazanç kırılganlıklarını azalttığı ortaya konmuştur (Bacon, 2005). Bu konudaki yaygın kanaat ise organik tarımın üretici gelirini arttırdığ1 yönündedir. Çünkü Uganda (Bolwing vd, 2009), Hindistan (Parvathi ve Waibel, 2016), Gana (Kleemann vd, 2014) ve Kenya'daki (Ayuya vd, 2015) saha bulguları sertifikasyonun üretici gelirini arttırdığı yönündedir. Ancak bu duruma çekimser ve alternatif yaklaşımların olduğu görülmektedir. Zira ABD'deki bir saha çalışmasında sertifikasyonun zorlu süreçlerinin üreticileri sertifikasyona katılım konusunda caydırıcı bir etkiye sahip olduğu sonucuna ulaşılmıştır (Veldstra vd, 2014). Bu konudaki daha dikkate değer başka bir bulgu ise Norveç'te yapılan bir saha çalışmasından elde edilmiştir. 2004-2007 yılları arasında sertifikasyondan kaydını sildiren katılımcıların \%17'si tarımı tamamen bırakmış, \%61'i konvansiyonel tarımla uğraşmakta ve \%21'i ise sertifikasız organik tarım faaliyetini devam ettirdiği 
görülmüştür. 2007 yılında yapılan çalışmada organik üreticilerin nerdeyse 4'te biri gelecek 5-10 yıl içerisinde sertifikasyonu bırakmayı planladığını belirtmiştir (Flaten vd, 2010). Bu konuda 3 farklı çıkarımdan bahsetmek mümkündür. Bunlardan belki de en çok göze çarpanı, organik tarımın küresel olarak artan popülaritesine karşın üreticilerin önemli bir kısmının organik tarımı sertifikasız olarak sürdürmek yerine konvansiyonel tarıma yönelmiş olmasıdır. Zira organik tarımla çoğu zaman çeliştiği düşünülen ve bilinen zararlı etkilerine karşın konvansiyonel tarımın hala önemini korumasıdır. Bu durum ise 'Katı sertifikasyon prosedürleri mi yoksa sürdürülebilir tarım mı?' sorusunu akıllara getirmektedir. Bir diğer husus ise üreticilerin bir kısmının organik tarım faaliyetlerini sertifikasız olarak devam ettirmesidir. Üzerinde durulması gereken bir diğer husus ise üreticilerin bir kısmının tarımsal faaliyetleri tamamen bırakmış olmasıdır. Yani bu gruptaki üreticiler ne konvansiyonel tarımı ne de sertifikasız organik tarımı tercih etmektedir. Şüphesiz bu 3 durumun da temelinde sertifikasyonun katı kuralları ile sertifikasyonla ilişkili ekonomik tercihler yatmaktadır. Araştırmacı ise bu durumun çözümünü 'ekonomik kaygı, çevresel tavır ve sertifikalı organik üretimle ilişkili düzenleyici meselelere dayanan politik tavsiyelerde' bulmaktadır (Flaten vd, 2010).

\subsection{Organik Tarımda Hükümet Dışı Organizasyonların (HDO) Rolü}

Organik tarım sektöründe hükümet dışı organizasyonlar son derece önemli rollere sahiptir. Bu kuruluşlarm en temel görevleri organik üretimi destekleyen üretici, tüketici, aracılar gibi her kesimden bireyi bir araya getirerek aralarındaki birlik ve dayanışma anlayışını güçlendirmek olduğu gibi bazen de birlikte hareket ederek kendi talep ve beklentilerini hem resmi yollarla hem de medya aracilığıyla ifade etmektedir. $\mathrm{Bu}$ durum ise organik pazardan üretimdeki sertifikasyona, hukuki düzenlemelere ya da ürünlerin tanıtımına kadar uzanan geniş bir yelpazede hükümet dışı organizasyonların üstlendikleri kritik rolleri göz önüne sermektedir.

Hatanaka (2010), HDO'ların organik ürün üretici ve tüketicilerini bir araya getiren faaliyetlerin öncüsü olarak sektörün gelişimine katkı sunması gerektiği fikrini belirtmiştir (Hatanaka, 2010). Ayrıca Brezilya'daki HDO'lar organik pazar içerisinde aktif bir rol üstlenmekte ve işlem maliyetlerini önemli ölçüde azaltarak sektörün gelişimine önemli katkı sunmaktadır (Blanc ve Kledal, 2012). Meksika örneğinde ise HDO'lar, küçük çiftçilere bazı resmi desteklerden fon sağlama imkânı sunarak üreticiye maddi destek sağlamaktadır (Tovar vd, 2005). Hindistan'daki bir saha çalışmasında organik karabiber üretiminin sertifikalandırılmasında hükümet dışı bir organizasyon öncülük etmiştir. Bu organizasyon, organik sertifika kapsamında yetiştirilen tüm ürünleri satın alarak ürünün pazarlanma sorununa çözüm üretmiştir. $\mathrm{Bu}$ durum organik ürünün pazarlanmasında HDO'ların ne kadar aktif bir rol üstlendiğini ortaya koymaktadır (Parvathi ve Waibel, 2016). Yine benzer şekilde HDO'lar Tropikal Afrika ülkelerinde ihracata yönelik sertifikalı organik ürün yetiştiriciliği yaparak ülke ve üretici kalkınmasına olumlu katkıda bulunmaktadırlar (Bolwing vd, 2009). 


\subsection{Konvansiyonel Tarıma Karşı Organik Tarım}

Organik ve konvansiyonel tarımın karşılaştırıldığı literatür araştırmasında en çok üzerinde durulan konu 'çevresel koruma ve sürdürülebilirliktir.' Bu konuda yapılan araştırmalarda ortaya çıkan yaygın görüş, organik tarımın konvansiyonel tarıma göre daha sürdürülebilir olduğu şeklindedir (Kings ve Ilbery, 2010; Tuomisto vd, 2012; Duram, 2000 ve Cobb vd, 1999;).

Sanayi devrimi öncesinde tarımsal üretim geleneksel yöntemlerle uygulanmaktayken sanayi devrimine teknolojik yeniliklerin de eklenmesiyle birlikte konvansiyonel üretim anlayışına geçiş süreci başlamıştır. Bunun temel sebebi ise birim alandan daha fazla ürün almak ve dolayısıyla kar etme düşüncesidir.

Sanayi devrimi öncesindeki tarım anlayışı günümüzde 'sertifikasız organik tarım' olarak nitelendirebileceğimiz yaklaşımla büyük oranda örtüşmektedir. Konvansiyonel tarımın aksine organik tarımda kimyasal ilaç ve gübre kullanılmamakta, ürünlerin genetiği üzerinde işlem yapılmamaktadır. Buna bağlı olarak da yetiştirilen organik ürünler daha güvenilir ve sağlıklı olarak nitelendirilmektedir (Storstad ve Bjorkhaug, 2004; Best, 2008 ve Lockie, 2006).

Sanayi devrimi ve teknolojik yeniliklerle birlikte organik yetiştiricilikten konvansiyonel üretime neredeyse küresel çapta geçiş gerçekleşmiştir. Ancak kimyasal ilaç ve gübrelerin konvansiyonel tarımda kullanılması sağlık, güvenlik, çevresel koruma, sürdürülebilirlik gibi endişelerin artmasına neden olmuştur (Febles-Gonzales vd; 2011; Crandfield, 2010 ve Carpenter, 2003). Bu durum son 20 ylllık zaman dilimi içerisinde konvansiyonel üretim modelinin prestijini olumsuz etkilemeye devam ederken organik üretimin azalan prestijini ise yükseltmektedir. Yani sanayi devrimi ve teknolojik gelişmelerle organik tarım aleyhine işleyen tarımsal geçiş, son dönemlerde organik tarımın lehine evrilmektedir. Ancak şunu da unutmamak gerekir ki gerek organik ürünlerin fiyatının pahalı oluşu gerekse dünya nüfusunun giderek artması konvansiyonel tarımın, yerini organik tarıma bırakacağ1 yönündeki düşünceleri en azından yakın gelecek için haklı çıkarmayacaktır.

Organik ve konvansiyonel tarım sistemleri birbiriyle kıyaslanırken iki tarım sistemi arasında bir takım bariz farklılıklar bulunmaktadır. Tablo 3 'te ele alınan kriterler açısından organik tarım konvansiyonel tarıma göre daha avantajlıyken bazı kriterlerde ise dezavantajlıdır. Organik tarımın avantajlı olduğu kriterler şunlardır: Ürünün satış fiyatı, insan ve çevre sağlığı, tarımsal ve çevresel sürdürülebilirlik. Konvansiyonel tarımın organik tarıma göre daha avantajlı olduğu kriterler ise şunlardır: Belirli standartlara göre üretme kriteri, birim alandan elde edilen üretim miktarı ve üretim zorluğudur. 
Tablo 3. Tarımsal Sistemlerde Avantaj ve Dezavantajlar

\begin{tabular}{|c|c|c|}
\hline Kriterler & Organik Tarımda & $\begin{array}{c}\text { Konvansiyonel } \\
\text { Tarımda }\end{array}$ \\
\hline Ürünün birim satış fiyatı & Daha yüksek & Daha düşük \\
\hline İnsan ve çevre sağlığı & Daha sağlıklı & Daha az sağlıklı \\
\hline Tarımsal ve çevresel sürdürülebilirlik & Daha yüksek & Daha düşük \\
\hline $\begin{array}{c}\text { Belirli standarda göre üretme } \\
\text { kriterleri }\end{array}$ & Daha katı & Daha serbest \\
\hline $\begin{array}{c}\text { Birim alandan elde edilen üretim } \\
\text { miktarı }\end{array}$ & Daha düşük & Daha yüksek \\
\hline Üretim zorluğu & Daha zahmetli & Daha az zahmetli \\
\hline
\end{tabular}

\subsection{Organik Üründe Tüketici Motivasyonu}

Tüketiciler sağlıklı ürün ve ürünlerin çevre üzerindeki etkisi konusunda endişe taşımaktadır (Clarke vd, 2008). Sertifikalı organik tarım ise tüketicilerin bu konudaki kaygılarını önemli ölçüde gidermektedir. Bu bağlamda kişileri organik ürün tüketmeye yönelten motivasyonlar birbirinden farklılık göstermektedir. Bu motivasyonların bir kısmı sağlık, gıda güvenliği, kalite gibi kişisel kaygılardan kaynaklanmaktayken bir kısmı da çevre sağlığı ve sürdürülebilirliği gibi çevresel kaygılardan kaynaklanmaktadır. Organik ürün tercihinde belirtilen diğer nedenler ise organik ürünlerin çevre dostu olması, tadının ve görünüşünün daha iyi olması, giderek yaygınlaşması ve güvenilir olmasıdır (Zepeda vd, 2006 ve Smith ve Marsden, 2004).

Danimarka'da uygulanan bir çalışmanın analiz sonuçları ortaya koymaktadır ki tüketiciler açısından gelişmiş hayvancılık uygulamaları ve çevresel koruma en önemli iki özelliktir. Sağlık ise üçüncü en önemli konu olarak belirtilirken tat ve tazelik ise en az önemli iki özellik olmuştur (Wier vd, 2008). Zepeda vd (2006)'ne göre tüketicileri organik ürün almaya teşvik eden en önemli faktör ürünün tadıdır. Ürünün organik olup olmadığ 1 ise ikinci en önemli özelliktir. Onu sağlık ve besleyicilik takip etmektedir. Bu konudaki diğer belirleyiciler ise ürünün GDO'lu olup olmadığı, tazeliği, güvenilir olması ve laboratuvar uygulamalarıyla küçük tarlalarda üretilip üretilmediğidir (Zepeda vd, 2006).

\section{TARTIŞMA VE SONUÇ}

118 makalenin eleştirel literatür analizinin yapıldığı bu çalışmadan elde edilen sonuçlar aşağıda maddeler halinde kısaca özetlenmiştir:

1) Organik tarım ile sürdürülebilir kısal kalkınma arasında yakın bir ilişki vardır.

2) Organik tarımın ekonomik çarpan etkisi ve kırsal istihdam yaratma potansiyeli vardir.

3) Organik üretim sertifikasına sahip olan üreticiler bulunmaktadır. 
4) Organik üretim sertifikasına sahip olmayan diğer üreticilerle kıyaslandığında daha fazla gelir elde etmektedir.

5) Organik tarım konvansiyonel tarıma göre daha sürdürülebilir bir tarımsal üretim şeklidir.

6) Organik tarım, çevre dostu bir uygulamadır.

7) Hükümet Dışı Organizasyonlar (HDO) organik ürünün yetiştirilmesinden pazarlanmasına kadar pek çok konuda organik üretime olumlu katkı sunmaktadir.

8) Tüketicileri organik ürün tüketmeye yönelten temel motivasyonlar sağlık, kalite ve çevresel koruma güdüsüdür.

Küresel anlamda organik tarım uygulamaları son yıllarda giderek yaygınlık kazanmaktadır. Türkiye'de de organik tarım $\mathrm{AB}$ destekleri ve resmi kurum destekleriyle son yıllarda yaygınlaşmaktadır.

Dünyada organik tarımın öncülüğünü Almanya, İngiltere, Hollanda ve ABD yapmaktadır. Organik tarımın kırsal alan üzerindeki çok yönlü etkisi onu bu ülkelerin gündeminde tutmaktadır. Bu etkileri şu şekilde sıralamak mümkündür:

a) Kırsal istihdam ve geliri arttırması

b) Doğal çevreyi koruması

c) Tarım alanlarını koruması

d) Topraktaki canlı ve mineral çeşitliliğine katkı sunması

e) Bitki ve hayvan çeşitliliğine katkı sunması

Organik tarımın yukarıdaki çok yönlü katkısına ek olarak toprak, su ve canlı çeşitliliğinin sürdürülebilirliğine de olumlu katkıda bulunmaktadır. Tüm bu etmenler aynı zamanda sürdürülebilir kırsal kalkınmanın da üzerinde önemle durduğu temel başlıklardır. Organik tarımın bu çok yönlü katkısı sürdürülebilir kırsal kalkınmayı da tesis etmede kullanılan temel argümanlardan bir tanesidir. Gelişmiş ülkelerin son zamanlı politikalarında şüphesiz en önemli ayaklardan birisi sürdürülebilir kırsal kalkınmanın sağlanmasıdır. Organik tarımın kırsal kalkınmayla birebir örtüşen bu ortaklığı onları birlikte ele almayı gerekli kılmaktadır. Yakın zamanlı küresel siyasetin üzerinde önemle durduğu 'sürdürülebilirlik ve kalkınma' başlıkları hem organik tarımı hem de kırsal kalkınmayı kapsamaktadır.

Konvansiyonel tarımın hem insan hem de çevre üzerindeki olumsuz etkilerinin ortaya çıkmasıyla gelişmiş ülkelerde insan sağlığına ve çevreye zararı olmayan belirli standartlara göre yetiştirilmiş ürün tüketimi konusunda farkındalık oluşmuştur. Bu konuda en güçlü alternatif ise organik tarım olarak düşünülmektedir.

Sonuç olarak organik tarımın gelecekte giderek artan bir öneme sahip olacağı açıktır. Çünkü organik tarım sağlık, çevresel sorunlar, kırsal kalkınma ve sürdürülebilirlik konularının önem kazandığı küresel politikalarda çözüm üreten bir faktör olarak düşünülmektedir. 


\section{KAYNAKÇA}

Alaeddinoğlu, F., \& Şeremet, M. (2016). Nature-Based Tourism in Turkey: The Yayla in Turkey's Eastern Black Sea Region. In Alternative Tourism in Turkey (pp. 71-86). Springer International Publishing.

Ayaz, N. (2015). Kırsal Turizm Geliştirme Sürecinde Belediye Başkanlarının Görüşleri Üzerine Bir Araştırma. Gazi Üniversitesi Turizm Fakültesi Dergisi, 2015(1), 1-26.

Ayuya, O. I., Gido, E. O., Bett, H. K., Lagat, J. K., Kahi, A. K. and Bauer, S. (2015). “Effect of Certified Organic Production Systems on Poverty among Smallholder Farmers: Empirical Evidence from Kenya." World Development 67: 27-37. doi:10.1016/j.worlddev.2014.10.005.

Bacon, C. (2005). "Confronting the Coffee Crisis: Can Fair Trade, Organic, and Specialty Coffees Reduce Small-Scale Farmer Vulnerability in Northern Nicaragua?" World Development 33 (3): 497-511.

Balaban, Y., (2014), Organik Tarım, Elma Yayınevi, Ankara.

Best, H. (2008). "Organic Agriculture and The Conventionalization Hypothesis: A Case Study From West Germany." Agriculture and Human Values 25: 95-106. doi:10.1007/s10460-0079073-1.

Blanc, J. and P.R. Kledal. (2012). The Brazilian Organic Food Sector: Prospects and Constraints of Facilitating The Inclusion of Smallholders. Journal of Rural Studies 28:142-154.

Bolwing, S. and Gibbon, P. (2009). “The Economics of Smallholder Organic Contract Farming in Tropical Africa." World Development 37 (6): 1094-1104.

Carpenter, D. (2003). "An Investigation Into The Transition From Technological to Ecological Rice Farming Among Resource Poor Farmers From The Philippine Island of Bohol." Agriculture and Human Values 20: 165-77.

Clarke, N., Cloke, P., Barnett, C. and Malpass, P., (2008). The Spaces and Ethics of Organic Food. Journal of Rural Studies 24:219-230.

Cobb, D., Feber, R., Hopkins, A., Stockdale, L., O'Riordan, T., Clements, B., Firbank, L., Goulding, K., Jarvis, S. and Macdonald, D. (1999). "Integrating The Environmental and Economic Consequences of Converting to Organic Agriculture: Evidence From A Case Study." Land Use Policy 16: 207-21.

Cranfield, J., Henson, S. and Holliday, J. (2010). "The Motives, Benefits, and Problems of Conversion to Organic Production." Agriculture and Human Values 27: 291-306.

Daugbjerg, C., Tranter, R., Hattam, C. and Holloway, G. (2011). “Modelling The Impacts of Policy On Entry Into Organic Farming: Evidence From Danish-Uk Comparisons, 19892007." Land Use Policy 28: 413-22. doi:10.1016/j.landusepol.2010.09.001.

De Master, K. (2012). “Designing Dreams or Constructing Contradictions? European Union Multifunctional Policies and the Polish Organic Farm Sector." Rural Sociology 77 (1): 89-109. doi:10.1111/j.1549-0831.2012.00071.x.

Duram, L. A. (2000). "Agents' Perceptions of Structure: How Illinois Organic Farmers View Political, Economic, Social, And Ecological Factors." Agriculture and Human Values 17: $35-48$. 
Febles-Gonzalez, J. M., Tolon-Becerra, A., Lastra-Bravo, X. and Acosta-Valdes, X. (2011). "Cuban Agricultural Policy in The Last 25 Years. From Conventional to Organic Agriculture." Land Use Policy 28: 723-35. doi:10.1016/j.landusepol.2010.12.008.

Flaten, O., Lien, G., Koesling, M., and Loes, A-K. (2010). “Norwegian Farmers Ceasing Certified Organic Production: Characteristics and Reasons." Journal of Environmental Management 91: 2717-26. doi:10.1016/j.jenvman.2010.07.026.

Haring, A. M., Vairo, M., Dabbert, S. and Zanoli, R. (2009). “Organic Farming Policy Development in The EU: What Can Multi-Stakeholder Processes Contribute?" Food Policy 34: 265-72.

Hatanaka, M. (2010). Certification, Partnership, and Morality in An Organic Shrimp Network: Rethinking Transnational Alternative Agrifood Networks. World Development 38:706716.

Kleemann, L.; A. Abdulai; and M. Buss. (2014). Certification and Access to Export Markets: Adoption and Return on Investment of Organic-Certified Pineapple Farming in Ghana. World Development 64:79-92.

Kings, D., and Ilbery, B. (2015). "The Lifeworlds of Organic And Conventional Farmers in Central-Southern England: A Phenomenological Enquiry." Sociologia Ruralis 55 (1): 6284. doi:10.1111/soru.12047.

Lobley, M., Butler, A. and Reed, M. (2009). "The Contribution of Organic Farming to Rural Development: An Exploration of The Socio-Economic Linkages of Organic and NonOrganic Farms in England." Land Use Policy 26: 723-35. doi:10.1016/j.landusepol.2008.09.007.

Lockie, S. (2006). “Capturing The Sustainability Agenda: Organic Foods And Media Discourses on Food Scares, Environment, Genetic Engineering, And Health." Agriculture and Human Values 23: 313-23. doi:10.1007/s10460-006-9007-3.

Lockie, S. and Halpin, D. (2005). “The 'Conventionalisation' Thesis Reconsidered: Structural and Ideological Transformation of Australian Organic Agriculture." Sociologia Ruralis 45 (4): 284-307.

Marshall, A. (2000). "Sustaining Sustainable Agriculture: The Rise and Fall of The Fund for Rural America." Agriculture and Human Values 17: 267-77.

McGreevy, S. R. (2012). “Lost in Translation: Incomer Organic Farmers, Local Knowledge, and The Revitalization of Upland Japanese Hamlets." Agriculture and Human Values 29: 393412. doi:10.1007/s10460-011-9347-5.

Michelsen, J. (2009). “The Europeanization of Organic Agriculture and Conflicts Over Agricultural Policy." Food Policy 34: 252-57. doi:10.1016/j.foodpol.2009.03.004.

Moseley, M.J. (1996). Baseline Studies for Local Rural Development Programmes: Towards a Methodology, Planning Practice and Research. 11(1):19-36.

Offermann, F., Nieberg, H., and Zander, K. (2009). "Dependency of Organic Farms on Direct Payments in Selected EU Member States:Today and Tomorrow." Food Policy 34: 273-79. doi:10.1016/j.foodpol.2009.03.002. 
Parvathi, P. and H. Waibel. (2016). Organic Agriculture and Fair Trade: A Happy Marriage? A Case Study of Certified Smallholder Black Pepper Farmers in India. World Development 77:206-220.

Pugliese, P. (2001). Organic Farming and Sustainable Rural Development: A Multifaceted and Promising Convergence, Sociologia Ruralis 41 (1): 112-30.

Smith, E. and T. Marsden. (2004). Exploring The 'Limits to Growth' in UK Organics: Beyond The Statistical Image. Journal of Rural Studies 20:345-357.

Sonderskov, K. M. and Daugbjerg, C. (2011). "The State And Consumer Confidence in EcoLabeling: Organic Labeling in Denmark, Sweden, The United Kingdom And The United States." Agriculture and Human Values, no. 28: 507-17. doi:10.1007/s10460-010-9295-5.

Stolze, M. and Lampkin, N. (2009). "Policy for Organic Farming: Rationale and Concepts." Food Policy 34: 237-44. doi:10.1016/j.foodpol.2009.03.005.

Storstad, O. ve Bjorkhaug, H. (2003). "Foundations of Production And Consumption of Organic Food in Norway: Common Attitudes Among Farmers And Consumers?" Agriculture and Human Values 20: 151-63.

Tovar, L.G., Martin, L., Cruz, M.A.G. and Mutersbaugh, T., (2005), Certified Organic Agriculture in Mexico: Market Connections and Certification Practices in Large and Small Producers. Journal of Rural Studies 21:461-474.

Tuomisto, H.L., Hodge, I.D., Riordan, P. and Macdonald, D.W., (2012). Does Organic Farming Reduce Environmental Impacts? A Meta-Analysis of European Research. Journal of Environmental Management 112:309-320.

Veldstra, M. D., Alexander, C. E. and Marshall, M. I., (2014). “To Certify or Not to Certify? Separating The Organic Production Nd Certification Decisions." Food Policy 49: 429-36. doi:10.1016/j.foodpol.2014.05.010.

Vogl, C. R., Kilcher. L. and Schmidt, H. (2005). Are Standards and Regulations of Organic Farming Moving Away from Small Farmers' Knowledge?. Journal of Sustainable Agriculture. 26 (1). pages: 5-26.

Vos, T. 2000. "Visions of The Middle Landscape: Organic Farming And The Politics of Nature." Agriculture and Human Values 17: 245-56.

Wier, M., O'Deherty Jensen, K., Morch Andersen L., and Millock, K. (2008). The Character of Demand in Mature Organic Food Markets: Great Britain and Denmark Compared. Food Policy 33:406-421.

Yavuzer, Ü. and Bengisu, G., (2015), Organik Hayvancılı, Nobel Yayınevi, Ankara.

Zagata, L. and Lostak, M. (2012). "In Goodness We Trust. The Role of Trust and Institutions Underpinning Trust in the Organic Food Market." Sociologia Ruralis 52 (4): 470-87. doi:10.1111/j.1467-9523.2012.00574.x.

Zepeda, L., Chang H.-S. and Leviten-Reid, C., (2006). Organic Food Demand: A Focus Group Study Involving Caucasian and African-American Shoppers. Agriculture and Human Values 23:385-394.

http://www.fibl.org/de/startseite.html (Erişim tarihi: 25.05.2016)

http://www.ifoam-eu.org/ (Erişim tarihi: 26.05.2016) 
R. Okudum, F. Alaeddinoğlu.../ Karabük Üniversitesi Sosyal Bilimler Enstitïsü Dergisi, 2017, 7 (1), 14-28

www.ifoam.gov (Erişim tarihi: 25.05.2016)

www.un.org (Erişim tarihi: 25.05.2016) 